\title{
INNOVATIVE LEARNING APPROACH IN THE FIELD OF AUTOMOTIVE
}

\section{Milan KOVÁC̆ - Michal DÚBRAVČÍK-Andrea LE $\check{S} K O V A ́$}

\begin{abstract}
This article deals about learning and training system applied at the Faculty of mechanical engineering, Technical university of Košice. Important part of students' education in the field of study named "Automotive production" at the FME, TU of Košice is to gain the skills in the field of design methods and model and prototype fabrication, automotive production organization and various aspects of automotive production, as an object of science, research and development. The article is focused on the case study.
\end{abstract}

Key words: innovative learning, training engineering skills for automotive, students' car.

\section{INOVATIVNÍ PŘÍSTUP KE VZDĚLÁVÁNÍ V OBLASTI AUTOMOBILOVÉ VÝROBY}

Resumé: Příspěvek uvádí charakteristiku systému vzdělávání, který je využíván na Strojní fakultě Technické univerzity v Košicích, v inženýrském studijním programu Automobilová výroba. Důležitou součástí vzdělávaní studentů $\mathrm{v}$ jejich laboratořích je získání dovedností z oblasti dizajnu, výroby modelů a prototypů automobilových komponentů prostřednictvím tréninkového př́stupu. Článek je prezentován jako př́padová studie aplikace inovačních metod v laboratorní výuce.

Klíčová slova: inovační vzdělávání, trénink inženýrských zručností, studentský automobil ICAR.

\section{Introduction}

Learning to think and learning to learn - these are the essential skills for student success in every curriculum area and academic pursuit. Modern educational practices are based on proven visual learning methodologies that help students think and learn.

Modern methods of tuition, with IC technology support, became a permanent section of the university study.

\section{Theoretical scope}

The training initiatives at the FME, TU of Košice are based on modern education methods: project based learning, learning-by-doing, action learning, visual learning, learning by practice, digital/virtual technology supported education [1].

\section{Project based learning method} characteristics:

Students work in groups to solve challenging problems that are authentic. Learners decide how to approach a problem and activities to purse. They gather information from a variety of sources and synthesize, analyse and derive knowledge from it. At the end, students demonstrate their newly acquired knowledge. Project based learning means systematic teaching method - learning through experiences.

\section{Visual learning method characteristics:}

Visual learning is a proven method in which ideas, concepts, data and other information are associated with images and represented graphically. With the powerful combination of visual learning and technology, students learn to:

- Clarify thoughts: students see how ideas are connected and realize how information can be grouped and organized. With visual learning, new concepts are more thoroughly and easily understood when they are linked to prior knowledge.

- Organize and analyse information: students can use schemes and plots to display large amounts of information in ways that are easy to understand and help reveal relationships and patterns.

- Integrate new knowledge: students better remember information when it's represented and learned both visually and verbally.

- Think critically: linked verbal and visual information helps students make connections, understand relationships and recall related details.

By representing information spatially and with images, students are able to focus on meaning, reorganize and group similar ideas easily, and make better use of their visual 
memory. Visual tools assist students in organizing their thinking, remembering information and many other skills necessary to participate effectively.

Learning-by-doing method characteristics: The conclusion of performing the education in the form of learning-by-doing is that it leads to significantly improved results and enhances the quality of training. The main advantages compared to conventional learning are project orientation, better motivation of beneficiaries who can verify the theoretical knowledge in practice and compare their results with others and also the improvement of their innovation thinking. Bonus effect of experiential learning is permanent need of solving some trivial or more complicated problems that rise during the work and makes it a routine, what leads to enhanced self-reliance of students.

Methods offer a wide range of benefits [2]:

- overcomes the dichotomy between knowledge and thinking, helping students to "know" and "do";

- supports students in learning and practicing skills in problem solving, communication;

- encourages the development of habits of mind associated with lifelong learning and career success;

- creates positive communication and collaborative relationship among diverse groups of students;

- meets the needs of learners with varying skill levels and learning styles.

\section{Web- based training (WBT) method} characteristics:

Web- based training can be defined as computerbased training designed around Web technologies and intended for delivery across networks. Internet-based training, Internet-based instruction, Web-based instruction, and Webbased learning are very similar with WBT method. Characteristics [3]:

- WBT, like computer-based training, is self-directed and self-paced. WBT takes advantage of the world of hypermedia to allow the user to take control of the learning process;

- WBT may be designed as individual instruction or group instruction. WBT expands upon computer-based training with group activities like discussion forums, mail lists, and chat sessions;

- Most of the instructional elements of WBT are delivered asynchronously; that is, the user sets his own pace and direction. No other users need be online at the same time. Chat, on the other hand, is an example of a synchronous training method that supports real-time group discussions;

- WBT is interactive. Users learn a task by applying knowledge in real-world activities. Through exercises, scenarios, and simulations, users interact with information presented in WBT lessons;

- WBT is not: simply a collection of information pages or an online book;

- WBT is designed to meet pre-determined and well-defined training objectives and tests the user's knowledge to determine the effectiveness of learning. As a result of tests, the training may adapt to the user's needs or even remedy deficiencies;

- WBT provides for managed instruction, whereby scores and trainee records are retained, curricula are controlled, and managers have the tools and information they need to monitor the training.

In the next chapter of this article is presented specific example of application new learning methods at the FME, TU of Košice.

\section{Automotive training laboratory}

Laboratories of Automotive Production at the FME, TU of Košice provide R\&D activities and education in bachelor, master and doctoral study. Functions [4]:

- structural analyses of modules and systems of car engine, transmission, control systems, dashboard module, bodywork, brake systems and so on (parameters, structure, material, technology, level of innovation),

- innovative projects and suggestions for production innovations in cars (structural and technological changes, design of mechanical components), 
- suggestions for projecting of laboratories, testing rooms and work places for montage,

- project suggestions of test methodics and equipments for testing of automobile components,

- measurement of functional characteristics of components - function tests on cars;

- measurement of electric characteristics of electronic elements of car,

- lifespan tests of components,

- design and production of component models,

- video and CD presentations of production methods, montage of systems and modules of cars, production factories, R\&D centres and testing rooms,

- searching, processing and analytical works with information for creation of innovative projects and strategies of factories, elaboration of diploma works and so on.

In this workspace it is possible to provide suitable conditions for tuition with classical as well as modern methods by a combination of various educational types - e.g. the Internet. Method based on using opportunities afforded by the newest information- communication technology is image projecting e.g. visual ecommunication.

Practical work in the laboratory can be demonstrated with a 3D scanner in a real time. Students have an opportunity to see the 3D Scanner software desktop and at the same time watch the object being manipulated with it. Picture (fig.1) represents the opportunities of ICT use in tuition.

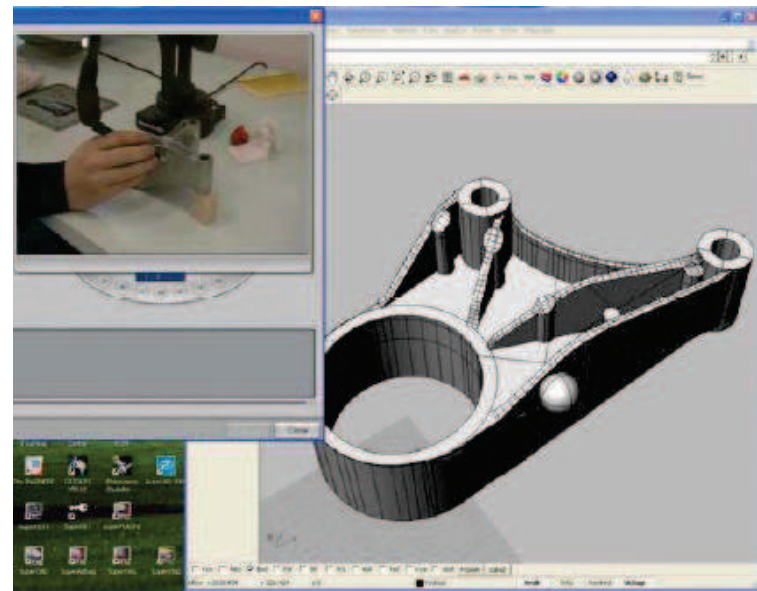

Fig. 1: Various views within the $3 D$ digitalization.

At the top on the top left hand side of the picture we can see a visual view of manipulation with the scanner projected from the $3 \mathrm{D}$ camera to the PC, and then beamed live onto the Internet. On the right hand side is software desktop on which students are able to watch software at work seeing the progress of manipulation being performed with the 3D scanner.

The images is then being simultaneously saved on a server and at the same time projected live on internet which enables e-Teaching tuition via internet. Students have the opportunity to watch the practice in classes on Internet or to see it from a record kept on the server in a database.

Demonstration is illustrated at fig. 2.

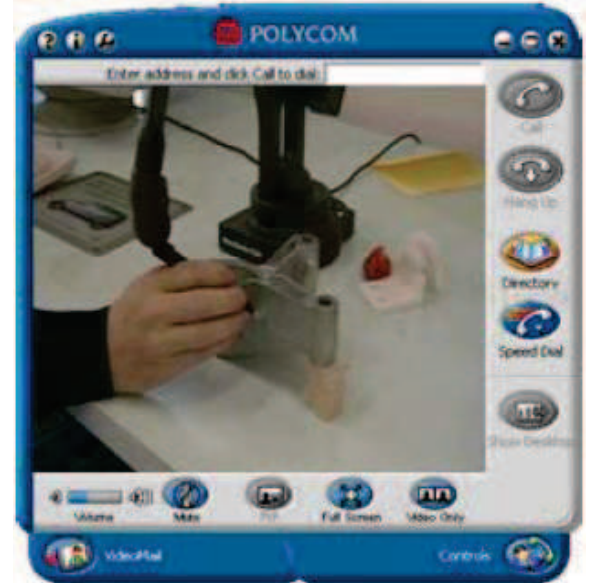

Fig. 2: e-Teaching using Polycom PVX software

4 Example of application new learning methods: Students Project ICAR

Students' car ICAR 2010 was introduced in 2011 at the Technical University of Košice. Name of the students' car is inferred from "Innovation Car student project". Car is actual project based on learning-by-doing education and 
training conception for Automotive production engineering study plan at the FME, TU of Košice.

Goal of this project was to design and to produce full functional car for free time, which could represent capabilities, knowledge and skills of the students in study programme "Automotive production". The car should impress with his originality, aggression, speed, and innovative features, sport look and should address young generation.

Project was designed to simulate real production plan in automotive companies, with real restrictions and with didactic goal of maximum team creativity.

Project was planned in these parts:

- to generate the concept variants of car;

- design proposals;

- graphic and computer proposals;

- reviews;

- prototyping;

- technical solutions, calculations and experiments;

- production and testing.

In 2009 obtained department of automotive production in cooperation whit partners from corporate sector damaged but functional car Skoda Fabia, which became a base for the ICAR project. After some technical modifications, functional platform accrued for future production steps. The preparing works lasted for 1 year. During this year students generated variants of new car, the design was specified, technical solution for door hinges was constructed, and that kind of preparations. All this proposals were in students powers. Though it was a prototype, bodyshell was made from fiberglass and other composite materials. The surface finishing composed final visual effect.

\section{ICAR features:}

- Materials applied: fiberglass, carbon, plastic, upholstery materials;

- Type: two seat roadster;

- Innovations: original interior and bodyshell whit vertical doors, increased engine power.

Technical specifications are described in tab. 1 .

Tab. 1: Technical specifications

\begin{tabular}{|l|l|}
\hline $\mathbf{L} / \mathbf{H} / \mathbf{W}[\mathbf{m m}]$ & $4180 / 1700 / 1395$ \\
\hline Wheel base [mm] & 2462 \\
\hline Wheel spacing [mm] & $1485 / 1475$ \\
\hline Cylinder/valve/fuel & $4 / 8 / \mathrm{D}$ \\
\hline
\end{tabular}

\begin{tabular}{|l|l|}
\hline Cubature [cm3] & 1896 \\
\hline Power [kW/(k)] & $88 / 120$ \\
\hline
\end{tabular}

\section{Concept design}

Single steps in concept design are illustrated on figures 3 to 5 .

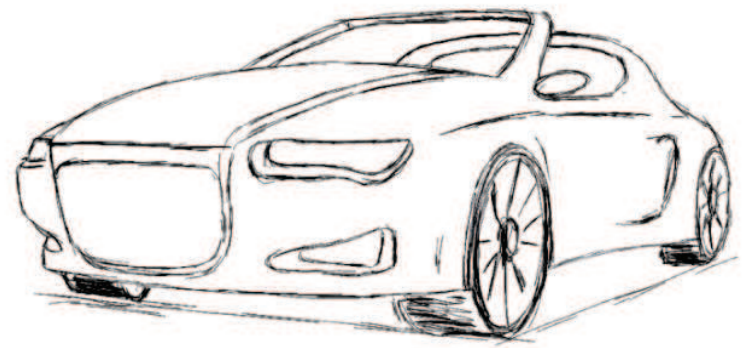

Fig. 3: First sketches

First sketches were made in the preparation phase on base of department layout by students.

There were several proposals. The final proposal was approved by entire team.

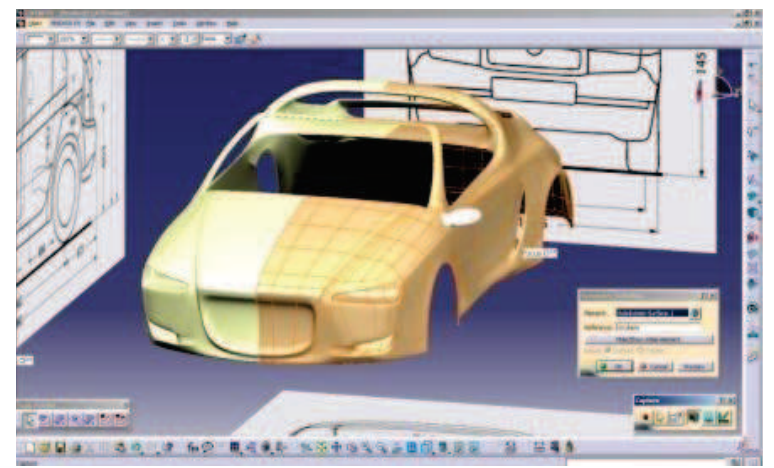

Fig. 4: CAD modelling (CATIA)

After sketching proposals a CAD model was created in CATIA. This model served for exact measurement and to fit new bodyshell to the Fabia platform.

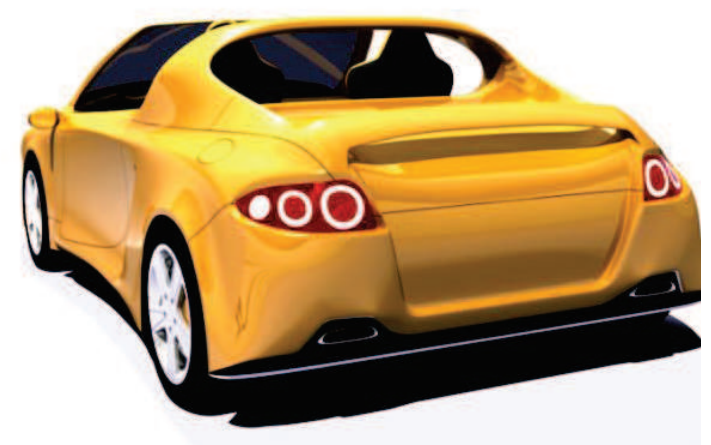

Fig. 5: Final CAD model

\section{Bodyshell and interior}

Figure 6 shows prepared Skoda Fabia platform before bodyshell production. 


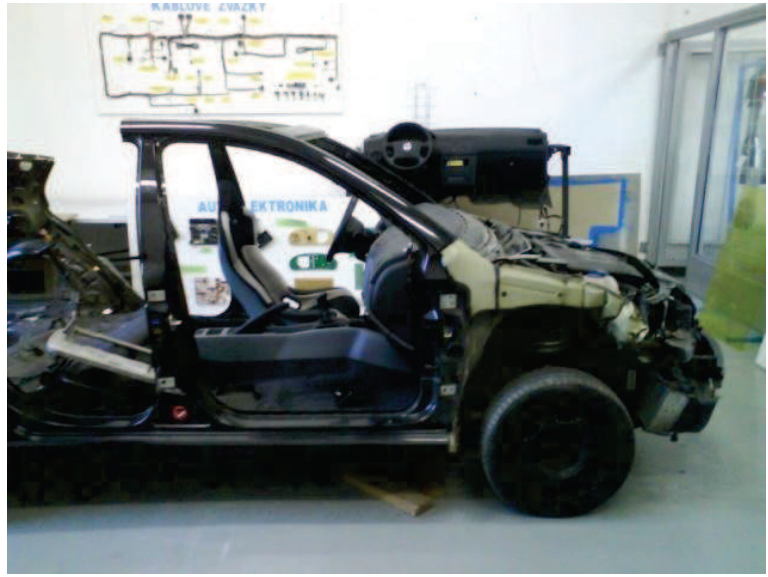

Fig. 6: The student's car platform

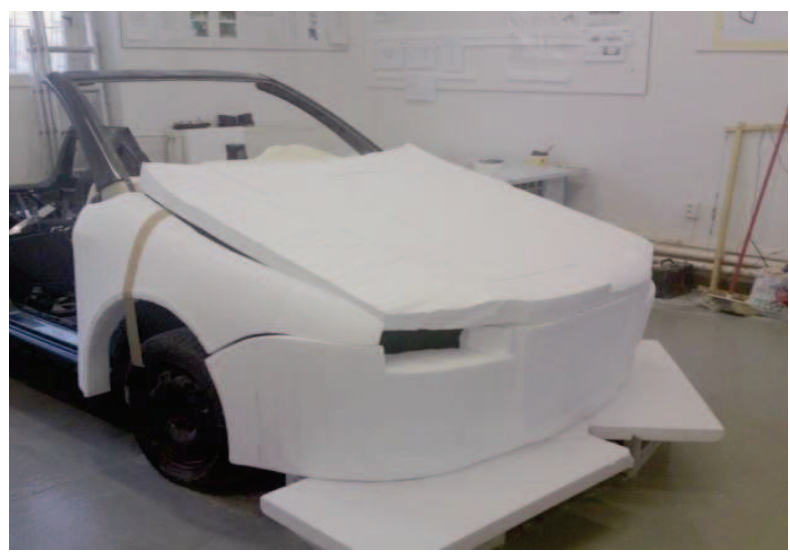

Fig. 7: Modelling and preparing of moulds for fiberglass in 1:1 scale

The bodyshell base parts were produced from polystyrene. These were removed after the fiberglass shell was made (fig. 7; 8). All bodyshells' parts were made separately after the polystyrene base was made. The parts from polystyrene were taken away from base platform and after that handled.

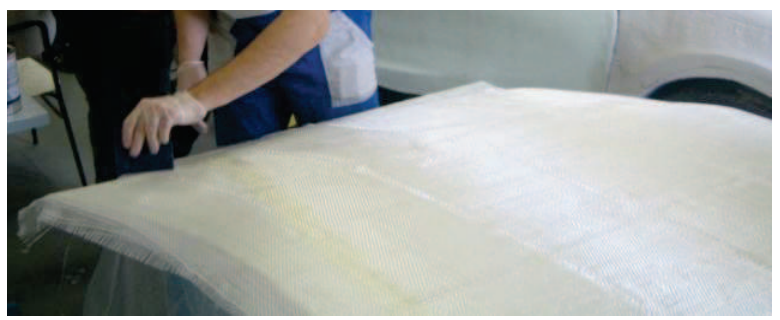

Fig. 8: Production of the bodyshell parts from fiberglass

The original Fabias' dashboard was fully made-over (fig. 9). In the centre of dashboard was installed tablet, which has been connected to car control unit. Via tablet is connection to internet, navigation and entertainment possible (fig. $10 ; 11$ ).

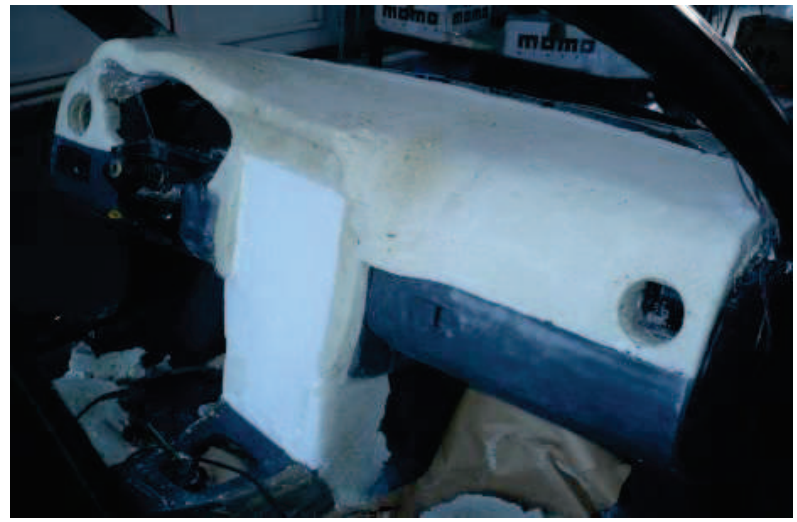

Fig. 9: Production of the dashboard

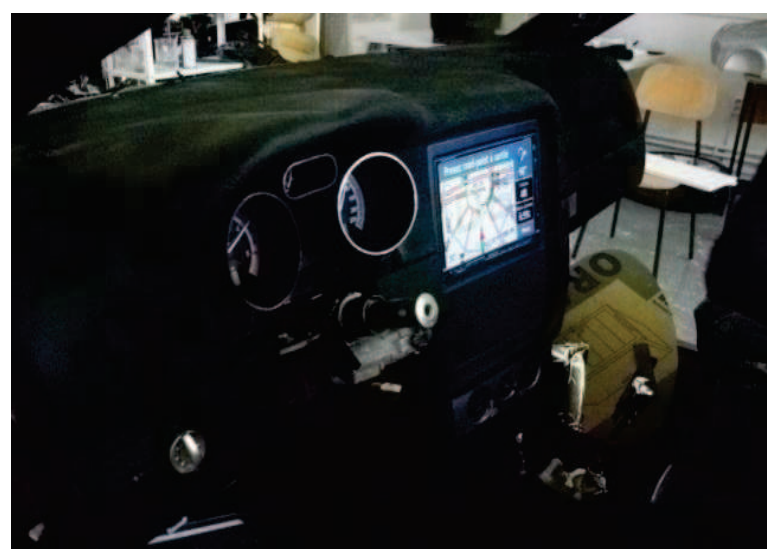

Fig. 10: Control elements assembly - tablet suggestion

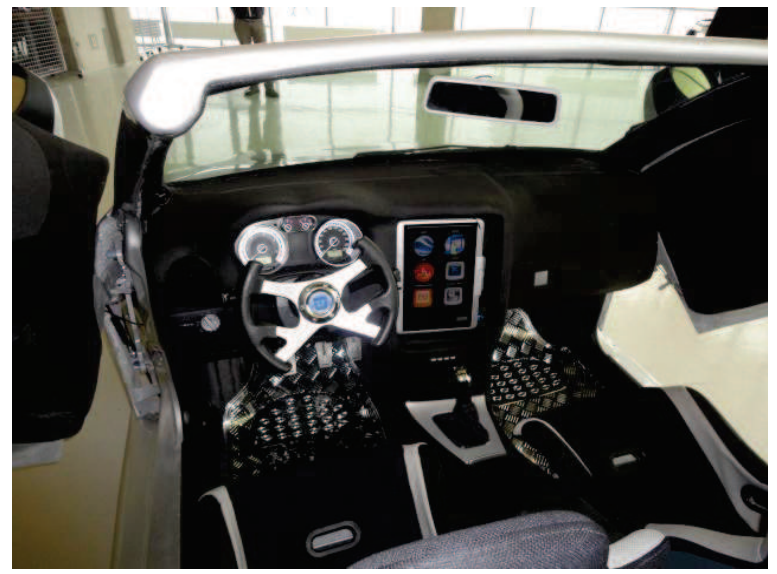

Fig. 11: The dashboard - final look

Final car

At fig. 12, 13 are presented final version of car shape. 


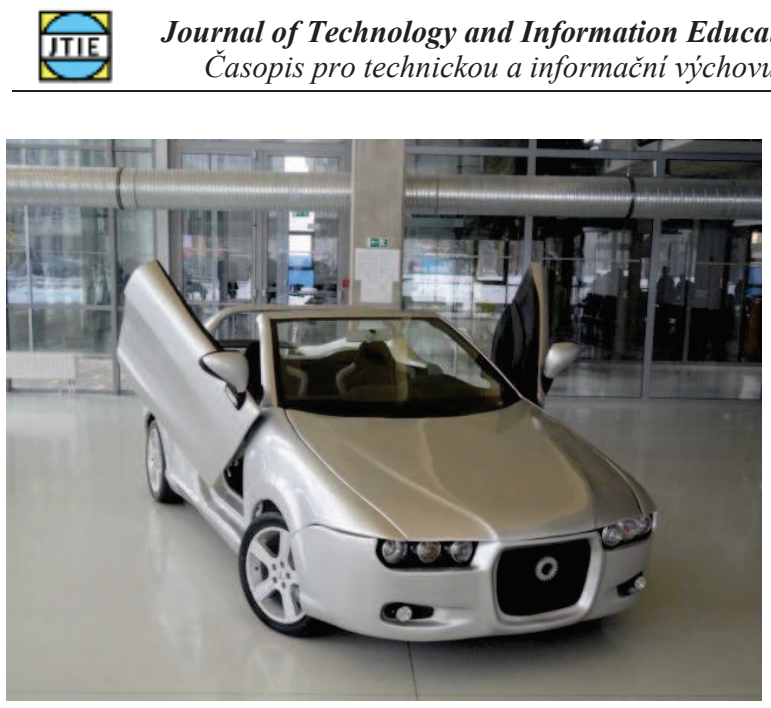

Fig. 12: Final car-front view

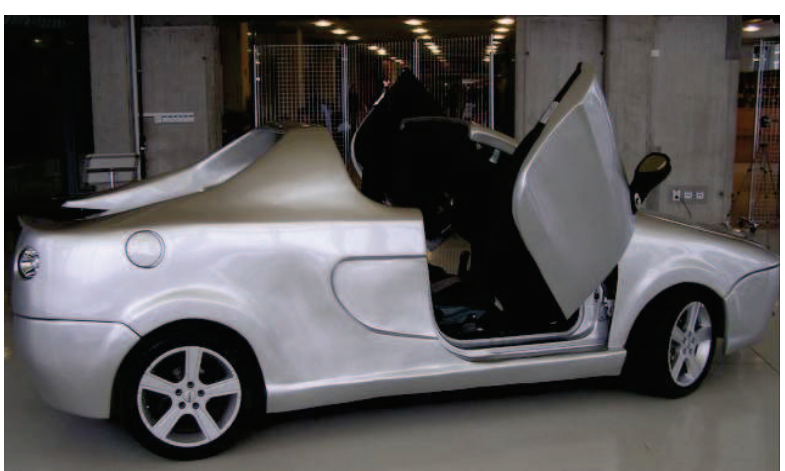

Fig. 13: Final car - side view

\section{Project resuming}

After ICARs introducing, there were some modifications made. Our thoughts were to innovate the car parts to the next level, such as proposition of a new design, applying new materials and other modifications. Nowadays there are 2 after projects running:

- new carbon shell seats - project fully in students management: design, materials;

- new door back mirrors - design, materials.

The ICAR project evoked interests between students. So we're standing against the challenge to build additional better and innovative cars.

\section{Conclusions}

The conclusion of performing the education and training in the form and using the approaches and methods described is that it leads to significantly improved results and enhances the quality of training.

ICAR project's contributions except the view of ability to build such car at Mechanical Faculty are:

- It emphasizes the need of supporting the automotive production study especially in innovations integration sphere.

- It emphasizes the need of flow of work between study classes.

- It extends technological and area options for experimental students work.

\section{Acknowledgments}

This contribution is the result of the project implementation: Center for research of control of technical, environmental and human risks for permanent development of production and products in mechanical engineering (ITMS: 26220120060) supported by the Research \& Development Operational Programme funded by the ERDF.

\section{References}

[1] BABJAK, Š.: Life- long learning system for the automotive training. In.: Equal for automotive No. 3/2007. TU Košice, 2007. ISBN 978-808073-870-9

[2] The University of Kentucky, Center for Visualization and Virtual Environments: http://www.vis.uky.edu/user_experience/advance d_visual_learning_sys.php

[3] www.webbasedtraining.com

[4] Technical University in Košice, Faculty of Mechanical Engineering, Laboratory of Automotive Production: http://web.tuke.sk/sjficav/en/index en.htm

[5] ŠVAČ, V., LEŠKOVÁ, A.: Inovatívne vzdelávanie pre automobilový priemysel. In: Marketing vzdelávacích inštitúcií : Vedecký zborník príspevkov. Trnava : UCM, 2007. s. 324333. ISBN 978-80-89220-86-1

[6] ŠVAČ, V.: Inovatívne vzdelávanie pre automobilový priemysel na Strojníckej fakulte Technickej univerzity v Košiciach. In: Technický týdeník. vol. 56, no. 17 (2008), p. 36. ISSN 00401064

[7] KENDER, Š., DÚBRAVČÍK, M.:: Technické parametre študentského auta. In: Auto masters. Č. marec (2011), s. 40. - ISSN 1338-3434 
Prof Ing. Milan Kováč, DrSc.

Ing. Michal Dúbravčík, PhD.

Ing. Andrea Lešková, PhD.

Katedra technológií a materiálov

Strojnícka fakulta

Technická univerzita v Košiciach
Mäsiarska 74

042 00, Košice, SR

Tel: +421 6023507

E-mail: milan.kovac@tuke.sk,

Www: http://www.sjf.tuke.sk/ktam/ 